\title{
Morphology, Molecular and Chromosomal Identification of Adenoscolex oreini Fotedar, 1958 (Cestoda: Caryophyllidea) from Jammu \& Kashmir, India
}

\author{
Ahmad F1, Mohi-ud-din Sofi $0^{2}$, Sofi TA $^{1 *}$, Sheikh BA $^{1}$ and Fazili \\ $\mathrm{KM}^{3}$ \\ ${ }^{1}$ Department of Zoology, University of Kashmir, India \\ ${ }^{2} \mathrm{G}$ B Pant University of Agriculture \& Technology, India \\ ${ }^{3}$ Department of Biotechnology, University of Kashmir, India
}

Research Article

Volume 1 Issue 1

Received Date: November 17, 2017

Published Date: December 06, 2017

${ }^{*}$ Correspondence author: Tanveer A. Sofi, Department of Zoology, University of Kashmir, Saloora Ganderbal Srinagar Kashmir, Srinagar, 190006, India, Tel: +919797127214, E-mail stanveer96@gmail.com

\section{Abstract}

Introduction: Caryophyllids are unique among Eucestoda in having a monopleuroid body plan i.e., they have neither internal proglottidization nor external segmentation and have a single set of reproductive organs. They are intestinal parasites of cypriniform and siluriform freshwater fishes; intermediate hosts are aquatic annelids. Knowledge of chromosome sets of caryophyllidean tapeworms has increased within the past 40 years. To date, 23 species of all four existing families have been studied cytogenetically and karyotypes of 14 species have been completed. The diploid chromosome number of all but one species ranges from 14 to 20; Caryoaustralus sprenti, represents the exception, having only six chromosomes. Adenoscolex oreini recovered during the present investigation belongs to this order.

Material and methods: The genomic DNA was isolated from the parasite of Adenoscolex oreini collected from the fish hosts of Carassius carassius; Schizothorax niger; Schizothorax curvifrons; Schizothorax labiatus; Schizothorax esocinus and Schizothorax plagiostomus from River Jhelum, River Sindh, Dal, Manasbal and Wular lakes of Kashmir valley by using standard ethanol precipation technique. The resultant DNA was separated by electrophoresis through $1.5 \%$ $(\mathrm{w} / \mathrm{v})$ agarose gel in TAE buffer stained with ethidium bromide, transilluminated under ultraviolet light and then photographed. The known size fragments of 100 bp ladder in agarose gel were used as marker. The rDNA regions spaning ITS regions were amplified by PCR.

Results: During the helminthological survey of fishes in Kashmir, India, specimens of genus Adenoscolex were collected from Carassius carassius and Schizothorax spp fishes. The morphological and molecular study inferred with partial sequence of 28S rDNA and chromosome analysis confirmed the specimens as Adenoscolex oreini. Phylogenetic analysis further confirmed its taxonomic status, as it comes under the same clade formed by other same family members reported from other geographical regions. This study first time describes the molecular identification of Adenoscolex oreini from Kashmir. 


\section{Cytology \& Histology International Journal}

Conclusion: It is concluded that Adenoscolex oreini can be differentiated on the basis of morphology, molecular and karyological features. By using molecular approach, there is marked difference between the nucleotide sequences of this tapeworm. The sequences of ITS region of $28 \mathrm{~S}$ rDNA gene have been proved a valuable tool for taxonomic studies of closely related taxa including cestodes from fresh water bodies of fishes. The variation in size of smallest bivalent and other bivalents indicates that the somatic chromosomes will show a marked variation in the length of longest and shortest chromosome in Adenoscolex oreini. It is apparent that the systematics of the Adenoscolex and its position among the basal tapeworms (Eucestoda) is still unresolved, because of the low number of molecular characters used and very low consistency index of the trees; it is premature to speculate on some of the molecular and evolutionary implications of the present data. New material of most genera is needed for analyses of molecular data.

Keywords: Cestode; Adenoscolex oreini; Kashmir; Carassius carassius and Schizothorax; 28S rDNA.

Abbreviations: PCR: Polymerase Chain Reaction; CI: Centromeric Indices; SM: Sub Metacentric; ST: Sub Telocentric; SD: Standard Deviation; NJ: Neighbour Joining Method MP: Maximum Parsimony; TCGA: The Centre for Genomic Applications

\section{Introduction}

The valley of Kashmir is gifted with a large number of Lakes, Rivers, streams, and ponds, which harbor variety of fishes and is famous for its natural fresh water Lakes, distributed in its length and breadth at varying altitudes. Important lakes and rivers of Kashmir valley surveyed are Wular Lake, Dal Lake, Manasbal Lake and Anchar Lake while among rivers; the River Jhelum and the River Sindh are the most important [1-6].

Cestodes have received considerable attention of systematists, not only because they are ubiquitously distributed, having radiated with their hosts into all habitats, but because of their importance as pathogens of humans and fishery (Cyprinus carpio, Carassius carassius, Schizothorax species) [7]. They exhibit a range of morphological, physiological, biochemical, and ecological adaptations, which make them suitable models for studies of various biological phenomena $[8,9]$. A high diversity of scolex morphology also makes cestodes a suitable model for studies on morphological adaptations [10,11]. Earlier approaches were mainly based on observed morphological characters without considering interspecific differences and without any knowledge on population variability and genetic characteristic, which resulted in inflation of descriptions of conspecific taxa. Thus, several approaches have recently been taken to more rigorously circumscribe species for producing accurate inventories.
Several tools for studying cestode micromorphology such as scanning and transmission electron microscopes have been used to provide accurate and, most importantly, more stable morphological characters $[12,13]$. Correctly stated -"it is much more 'scientific' to identify specimens with machines than doing it by simply looking at them", molecular approaches are now integrated with morphological ones to provide much reliable results [14-17].

Caryophyllids are unique among Eucestoda in having a monopleuroid body plan i.e., they have neither internal proglottidization nor external segmentation and have a single set of reproductive organs. They are intestinal parasites of cypriniform and siluriform freshwater fishes; intermediate hosts are aquatic annelids Knowledge of chromosome sets of caryophyllidean tapeworms has increased within the past 40 years [1]. To date, 23 species of all four existing families have been studied cytogenetically and karyotypes of 14 species have been completed. The diploid chromosome number of all but one species ranges from 14 to 20; Caryoaustralus sprenti, represents the exception, having only six chromosomes [2]. Adenoscolex oreini recovered during the present investigation belongs to this order.

The present aim was to carry out modern systematic studies to carry out Molecular taxonomy of Adenoscolex spp. from fishes of Kashmir valley by isolating the genomic DNA of the parasites using a standard SDSprotinase $\mathrm{K}$ procedure, Polymerase chain reaction (PCR); DNA sequencing and chromosomal analysis of these parasites, so as to define or redefine the new genera and species of the helminth parasites of fishes in Kashmir valley. This study would lay down the foundation for the establishment of database of parasitofauna of fishes in water bodies of Kashmir Valley. 


\section{Cytology \& Histology International Journal}

\section{Materials and Methods}

Collection of the Hosts: The fish hosts examined during the present study includes Schizothorax esocinus Heckel, 1838; Schizothorax plagiostomus Heckel, 1838; Schizothorax curvifrons Heckel, 1838; Schizothorax niger Heckel, 1838; Schizothorax labiatus McClelland, 1842; and Carassius carassius. Ten to fifteen fishes per survey were collected using gill nets or bought directly from fisherman. The live fishes were killed by a blow on the top of the cranium and were subsequently dissected by making an insertion from the anus towards the head.

Collection of Parasites: Fishes collected from water bodies were taken to laboratory, Department of Zoology, University of Kashmir and were immediately dissected. An incision was made in the mid-ventral body, cutting around the anus and urogenital opening. The entire alimentary canal and other visceral organs were detached and kept in separate Petri dishes containing normal saline $(0.65 \% \mathrm{NaCl})$. With the aid of magnifying glasses, these detached organs were searched for parasites. The parasites recovered were kept in normal saline $(0.65 \mathrm{NaCl})$ for some time.

Identification of Parasites: Parasitic specimens were identified using reference keys [18-21].

\section{Molecular Characterization}

DNA Extraction: Identified specimens of Cestodes were fixed in $96-100 \%$ ethanol. The genomic DNA was isolated from the parasite of Adenoscolex oreini collected from the fish hosts of Carassius carassius; Schizothorax niger; Schizothorax curvifrons; Schizothorax labiatus; Schizothorax esocinus and Schizothorax plagiostomus from River Jhelum, River Sindh, Dal, Manasbal and Wular lakes of Kashmir valley by using standard ethanol precipation technique [3]. The resultant DNA was separated by electrophoresis through $1.5 \%(\mathrm{w} / \mathrm{v})$ agarose gel in TAE buffer stained with ethidium bromide, transilluminated under ultraviolet light and then photographed. The known size fragments of $100 \mathrm{bp}$ ladder in agarose gel were used as marker. The rDNA regions spaning ITS regions were amplified by PCR (Table 1).

\begin{tabular}{|c|c|c|c|c|}
\hline \multirow{2}{*}{$\begin{array}{c}\text { Adenoscolex oreini } \\
\text { Fotedar, 1958 }\end{array}$} & \multicolumn{2}{|c|}{ Primer Designed (5.8S- ITS-2) } & $\begin{array}{c}\text { GenBank Accession } \\
\text { Number }\end{array}$ & Author and Year \\
\cline { 2 - 3 } & Forward & 5/-GTCGATGAAGAGCGCAGC-3/ & $\begin{array}{c}\text { EMBLZ269; AF229028 \& } \\
\text { AF229029 }\end{array}$ & {$[22,23]$} \\
\cline { 2 - 5 } & Reverse & 5/-AGGAGGCGAATCACTAT-3/ & \multicolumn{2}{|c|}{ SUB2816972 Adenoscolex oreini complete sequence. } \\
\hline \multicolumn{2}{|l|}{ Sequences submitted to GenBank } & \multicolumn{3}{|c|}{} \\
\hline
\end{tabular}

Table 1: Primers used.

Polymerase Chain Reaction (PCR): PCR was performed using the primer pairs for (ITS1 and ITS2), which were selected based on conserved sequences of Adenoscolex spp. PCR was carried out in a $25 \mu$ reaction volume, containing 50-100 ng of genomic DNA with 20 pmols of the primer (both forward and reverse). The PCR amplification of ITS1 and ITS2 regions was performed following the standard protocol, with minor modifications. The PCR products were run in $1.5 \%$ agarose gel to determine their size, with a 100 bp ladder and viewed in Kodak Gel logic 100 imaging system and purified by using spin columns [24]. The thermal gradient of these marker regions started with an initial denaturation at $94{ }^{\circ} \mathrm{C}$ ( 5 minutes), denaturation for 35 cycles $\left(94^{\circ} \mathrm{C}\right.$ for 30 seconds), annealing, $28 \mathrm{~S}$ at $55{ }^{\circ} \mathrm{C}(2$ minutes), extension $72^{\circ} \mathrm{C}(2$ minutes $)$ and final extension at $72^{\circ} \mathrm{C}$ ( 7 minutes).

\section{Sequencing of the Amplified Product}

The purified products were bidirectionally sequenced using the forward and reverse primers using automated sequencers- ABI Prism 3130XL Genetic Analyzer (Applied Biosystems, California, USA) with Big Dye (3.1) terminator protocol at UPE Central
Instrumentation Facility of School of Life Sciences, North-Eastern Hill University, facility at The Centre for Genomic Applications (TCGA), New Delhi was used. Sequencing was performed five times each to avoid any ambiguity. All sequences obtained were deposited in GenBank using the submission tool Bankit and their accession numbers acquired.

\section{Karyology}

Whole living specimens of Adenoscolex spp. were placed in physiological saline $(0.65 \% \mathrm{NaCl})$ containing colchicine $(0.05 \%)$ for $3-4$ hours at room temperature and transferred into distilled water for about one hour for hypotony and fixed in ethanol-glacial acetic acid (3:1), with two changes, 15 minutes each. Spread preparation of mitotic and meiotic chromosomes was made as described by Petkeviciute [25]. Small posterior mature portions of fixed worms were transferred into drop of $60 \%$ acetic acid on a slide and torn into fine pieces with the help of tungsten needles. The slides were then placed on a heating plate at $45^{\circ} \mathrm{C}$ and the drop of cell suspension was slowly drawn along the slide until it evaporated. Slides were dehydrated in an 


\section{Cytology \& Histology International Journal}

ethanol series $(30 \%, 50 \%, 70 \%, 90 \%$ and $100 \%, 5$ minutes each) and stored at $-20^{\circ} \mathrm{C}$. Slides were stained with $4 \%$ Giesma solution (pH. 6.8) in phosphate buffer for 30 minutes, rinsed in tap water and allowed to dry. The best chromosome plates were photographed and used for morphological studies.

\section{Photomicrography}

Leica DM LS2 trinocular photomicroscope with 100X $\mathrm{x} 10 \mathrm{X}$ magnification lens was used for taking the photographs and analyzes the chromosomes. The photographs were then developed on Kodak high quality photo paper. For karyotyping, chromosomes were cut out of the photomicrographs and paired on the basis of size and centromere position. The homologues were cut and arranged in metacentric, submetacentrics, meta-submetacentric, telocentric, subtelocentrics and acrocentric pairs of chromosomes arbitrarily. Relative lengths of chromosomes were calculated by the division of the individual chromosome length by the total haploid length and centromeric indices (ci) were determined by division of the length. Measurements are based on all chromosomes from 10 best metaphase spreads of parasites. The terminology relating to centromere position follows that of Levan et al. 1964. A chromosome is metacentric $(\mathrm{m})$ if the ci falls in the range of 37.5-50.0, submetacentric ( $\mathrm{sm}$ ) if 25.0-37.5, subtelocentric (st) if 12.5-25.0; acrocentric (a) if $<12.5$ and telocentric if 0 . When the centromere position was on the borderline between two categories, both are listed.

\section{Statistical Analysis}

Parametric as well as the non-parametric tests were used for analyzing relative length of chromosomes. A computer program (Minitab for windows) was used for data analysis. The descriptive data was given as a mean \pm standard deviation (SD). Chi-Square analysis was used to see the statistical significance in chromosome lengths. Pearson's correlation was used to find correlation between different species of helminths. Correlation analysis of data was carried out by using SPSS 16.5 package programme. Student's t-test was used to test the differences which were considered to be significant when the p-value obtained was less than 0.05 .

\section{Results}

\section{Morphology}

Generic Diagnosis: Smooth scales with well marked gland cells which are continued in body region, cirrus sac and utero-vaginal canal open separately at the beginning of posterior seventh of the body; lower horns of ovary bent inwards giving the appearance of inverted 'A', uterine coils extended beyond anterior horns of ovary but never anterior to cirrus sac; well developed receptaculum seminis; vitelline fields partly cortical and partly medullary being mostly at the level of inner longitudinal muscle layer; post-ovarian vitelline were present.

Species Identification: Comparatively smaller than Adenoscolex fotedari (about 38mm); No. of excretory vesicles 14-18; Shape of ovary like inverted 'A' lower horns of which are strongly bent inwards. Whilest in Adenoscolex fotedari ovary is $\mathrm{H}$-shaped and the two horns of ' $\mathrm{H}$ ' are not bent on either side; number of excretory vesicles 18-30 (Table 2).

\begin{tabular}{|c|c|c|c|c|}
\hline Particulars & Fayaz, 1993 & Ashiq, 2008 & Fayaz et al 2009 & Present study \\
\hline $\begin{array}{c}\text { Total body } \\
\text { length }\end{array}$ & 49.5 & 30.5 & 51 & $32-37$ \\
\hline Scolex & $0.87-1.64$ & $1.38 \times 0.9$ & $0.84-1.06$ & $0.90-1.40$ \\
\hline Neck & $1.0-1.1$ & --------- & $1.0-1.1$ & $0.9-1.1$ \\
\hline Testes & $\begin{array}{c}0.144-0.224 \times 0.048- \\
0.192 \\
\end{array}$ & $\begin{array}{c}0.18-0.21 \times 0.09- \\
0.16 \\
\end{array}$ & $0.15-0.24 \times 0.050-0.19$ & --------- \\
\hline Vas deference & --------- & $0.5 \times 0.45$ & -------- & -------- \\
\hline Ovary length & --------- & 2.15 & --------- & --------- \\
\hline Ovary width & -------- & 0.5 & -------- & -------- \\
\hline Wings of ovary & $1.4-2.7 \times 0.17-0.3$ & -------- & $1.46-2.5 \times 0.17-0.5$ & --------- \\
\hline Ovary isthmus & $0.31-0.71 \times 0.07-0.16$ & --------- & $0.35-0.73 \times 0.07-0.18$ & $0.33-0.71 \times 0.06-0.15$ \\
\hline Egg & $\begin{array}{c}0.052-0.076 \times 0.028- \\
0.056\end{array}$ & $\begin{array}{c}0.52-0.06 \times 0.23- \\
0.26\end{array}$ & $\begin{array}{c}0.059-0.074 \times 0.028- \\
0.059\end{array}$ & $0.050-0.071 \times 0.027-0.055$ \\
\hline Host & Schizothorax spp. & Schizothorax spp. & Schizothorax spp. & $\begin{array}{c}\text { Carassius carassius \& Schizothorax } \\
\text { spp. }\end{array}$ \\
\hline Site & Intestine & Intestine & Intestine & Intestine \\
\hline
\end{tabular}

Table 2: Comparative characteristics (measurements in mm) of Adenoscolex oreini Fotedar, 1958. 
Description: Body elongated with unarmed scolex. Mature worm broader and thicker in posterior part of the body. Gland cells developed extensively in scolex region being visible to naked eye, extended posteriorly in 3 well-developed columns for more than 3 quarter of anterior body length. A single set of male and female genital organs open separately to posterior end through male and female genital openings (Figures $1 \& 2$ ). Testis and vitellaria scattered while other genital organs restricted to posterior $1 / 7^{\text {th }}$ of body. Testis rounded, extended from scolex to cirrus pouch, bounded by vitelline follicles, vas deferens loosely convoluted tube, median anterior to cirrus sac. Cirrus sac muscular and pear shaped. Vitellaria numerous. Ovary single at $1 / 7^{\text {th }}$ posterior end of the body more or less $\mathrm{H}$ shaped. Two long limbs connected by a transverse ovarian isthmus Uterus coiled structure containing ova at different stages of development unite with vagina forming an utero-vaginal chamber to open exterior by female genital aperture. Capsules operculate ovoid, boat shaped with a small protuberance near basal region.

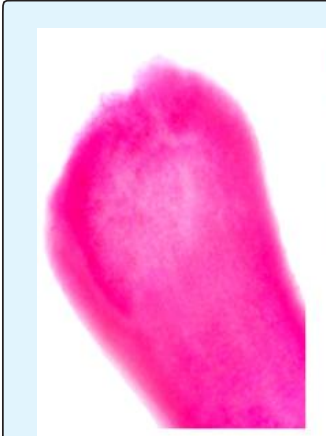

A

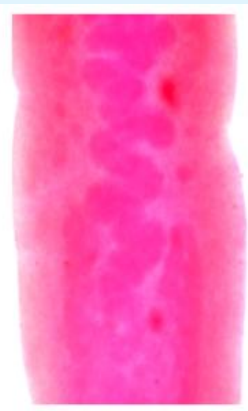

B

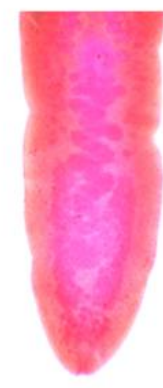

C
Figure 1: Photograph of Adenoscolex oreini Fotedar, 1958. A-Anterior end; B-Middle region; C-Posterior end.

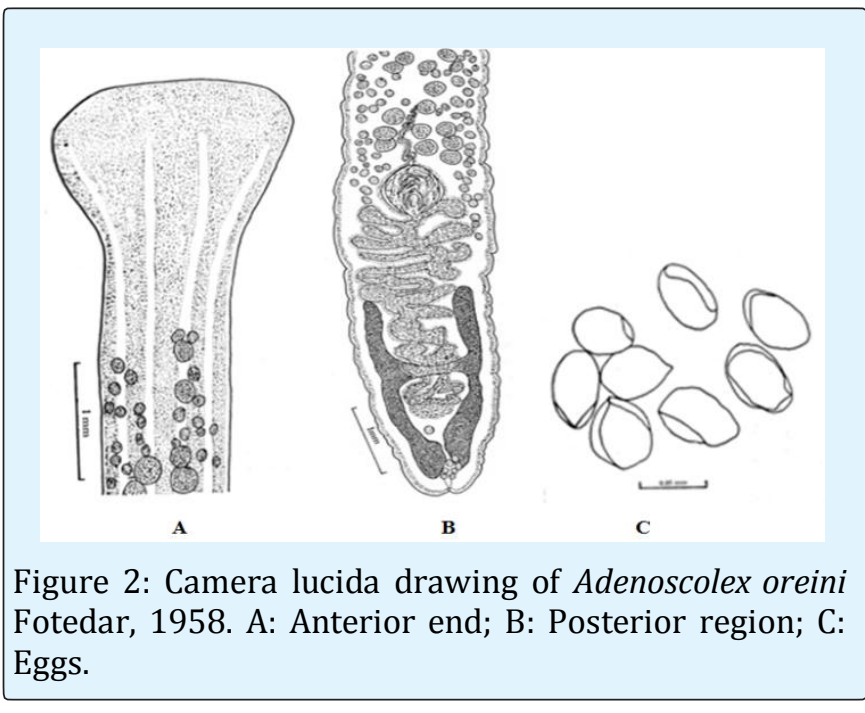

Remarks: From the above Table with regard to morphological characteristics/measurements of the parasite, it shows close resemble with Adenoscolex oreini. The identifying characters include; scolex and neck, Body length $30-51 \mathrm{~mm}$, ovary isthmus and egg size. The studies are in close confirmity with that of Fayaz; Ashiq and Fayaz, et al. [26-28].

\section{Molecular characterization}

PCR amplification was carried out to amplify ITS region by using Automated sequencers-ABI prisim 3130XL Genetic Analyzer (New Delhi-India). The size of the amplified product was found to be $954 \mathrm{bp}$ long (Figure 3). In BLAST search of the sequence, it showed similarity with other Cestodes. The sequence obtained was submitted to GenBank SUB2816972 (Table 3). Sequences were compared with other sequences of Cestodes available in GenBank. When the BLAST search was performed, the query sequence showed maximum similarity with $28 \mathrm{~S}$ sequence of Breviscolex spp. which belongs to the same family Capingentidae. The BLAST hits show that the sequences of the Adenoscolex oreini are close to those of Breviscolex orientalis, since there is no information available in GeneBank for ITS sequences pertaining to Adenoscolex species. The pairwise alignment of the ITS sequences and the flanking regions of the query sequences with the sequences of Breviscolex orientalis showed the presence of $9.22 \%$ mismatches with $0.94 \%$ gaps. All positions containing gaps and missing data were eliminated. The results obtained through Neighbour Joining method (N)) and Maximum Parsimony (MP) are constructed (Figure 4).

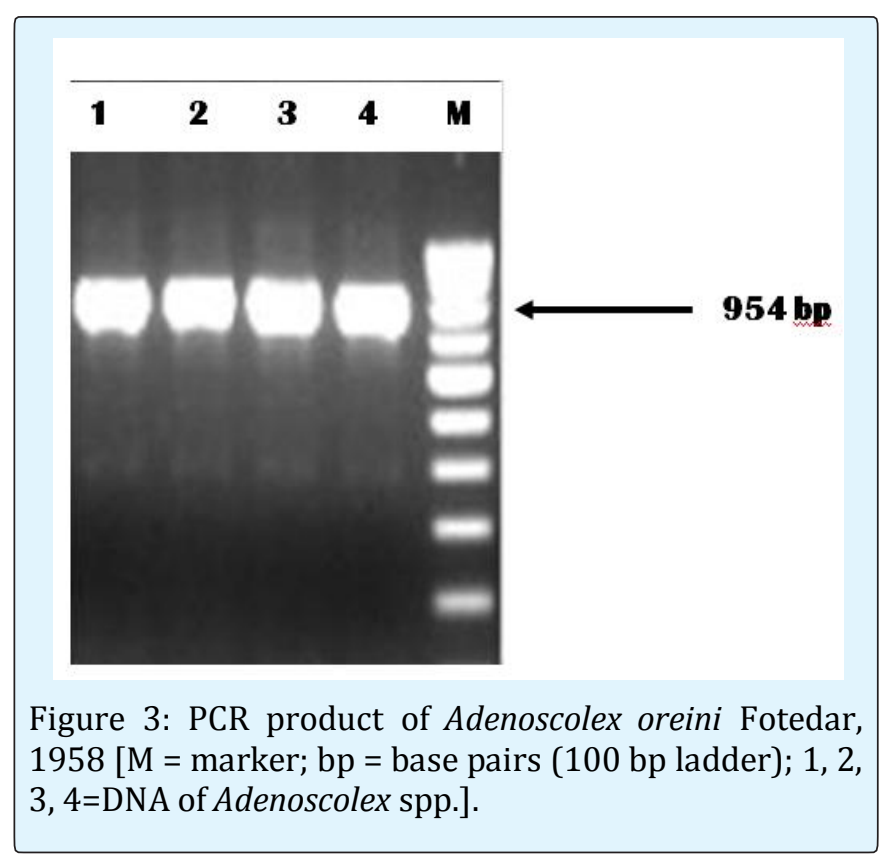




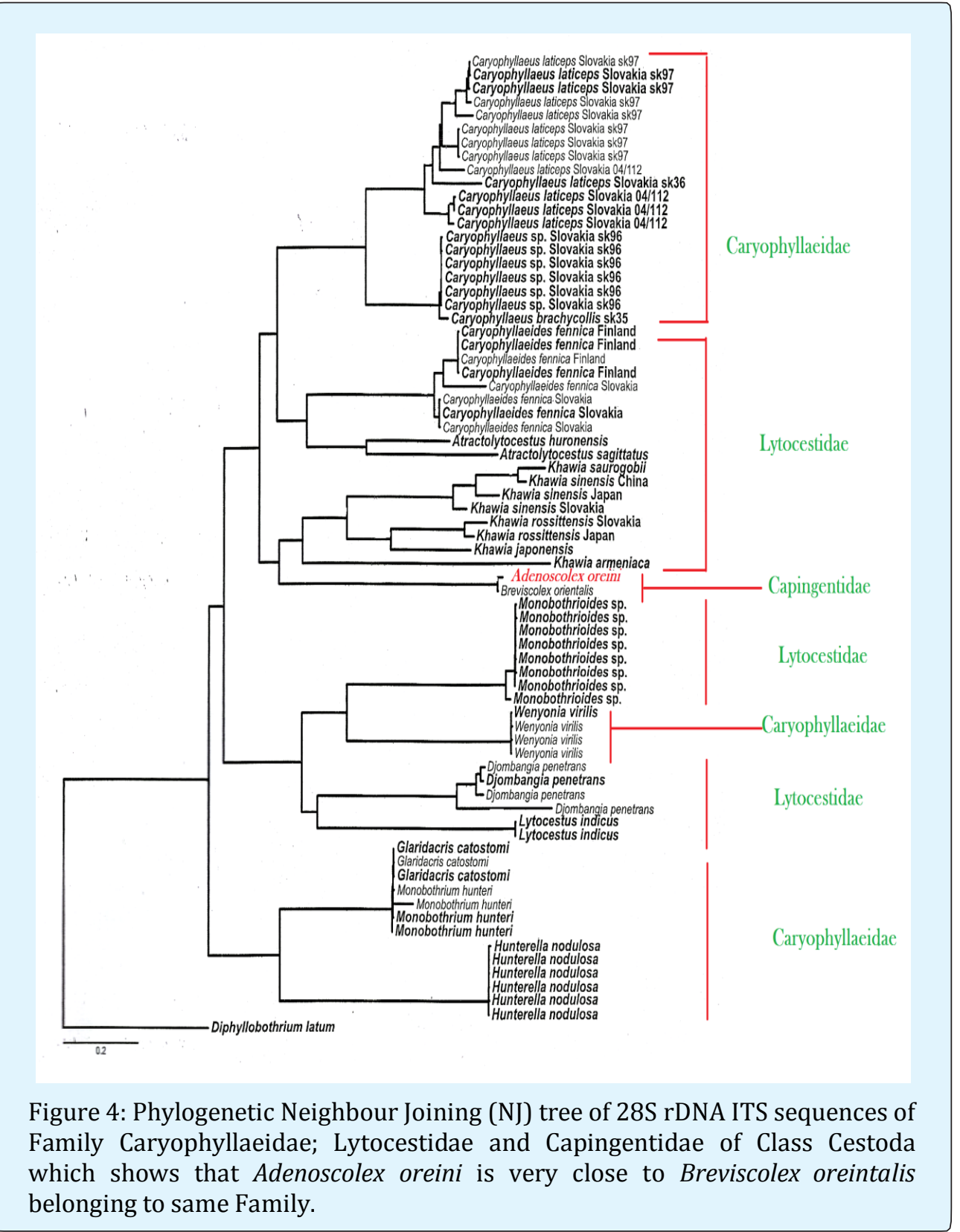

\begin{tabular}{|c|c|c|c|c|c|c|c|}
\hline S. No. & Cestode Species & Host & $\begin{array}{c}\text { GenBank } \\
\text { Accession No. }\end{array}$ & Family & $\begin{array}{c}\text { Base } \\
\text { pairs }\end{array}$ & Authors & Country \\
\hline 1 & $\begin{array}{c}\text { Adenoscolex oreini } \\
\text { Fotedar, 1958* }\end{array}$ & $\begin{array}{c}\text { Carassius carassius; } \\
\text { Schizothorax niger; } \\
\text { Schizothorax } \\
\text { curvifrons; } \\
\text { Schizothorax labiatus; } \\
\text { Schizothorax } \\
\text { plagiostomus }\end{array}$ & SUB2816972 & Capingentidae & $954 \mathrm{bp}$ & Present study & India \\
\hline 2 & $\begin{array}{c}\text { Breviscolex } \\
\text { orientalis }\end{array}$ & Hemibarbus barbus & AF286978 & Capingentidae & $2075 \mathrm{bp}$ & Olson et al.,[2001] & Japan \\
\hline 3 & $\begin{array}{c}\text { Breviscolex } \\
\text { orientalis }\end{array}$ & Hemibarbus barbus & JQ034117 & Capingentidae & $1605 \mathrm{bp}$ & Brabec et al. [2012] & Japan \\
\hline
\end{tabular}

Table 3: Cestode species used for molecular comparison of ITS rDNA sequences along with their hosts, country and GenBank accession numbers for corresponding sequences (*Query sequence). 
It is observed that Adenoscolex oreini having GenBank accession number SUB2816972 shows 90.78\% similarity with that of Breviscolex orientalis having JQ034117.1 GenBank accession number. Out of 954 base pairs of Adenoscolex oreini 866 bp are identical with that of Breviscolex orientalis with 9 gaps.

\section{Karyology analysis}

Analysis of mitotic metaphase spreads from seven specimens showed that the modal diploid complement of Adenoscolex oreini contains 20 chromosomes $(2 n=20)$. The karyotype (Figure 5a \& 5b) included eight metacentric; one submetacentric and one acrocentric chromosome pair. First four pairs of metacentric elements are distinctly larger than the remaining chromosomes and contributed $48.62 \%$ to the total chromosome length. The chromosomes are middle sized; the largest measured $8.56 \mu \mathrm{m}$ and the smallest were $1.94 \mu \mathrm{m}$ long (Table 4). The total chromosome length of the haploid complement was $58.29 \mu \mathrm{m}$. Fundamental arm number is 38. The homologues of pairs 6 and 7 could not be distinguished clearly and are statically less significant (Students T-test; $\mathrm{P}<0.05$; $\mathrm{P}=0.003$ ). First three pairs of chromosomes are all metcentric and there is less difference of their relative lengths and are statically less significant $\mathrm{P}<0.05$; $\mathrm{P}=0.008$; Students T-test). Last three pairs of chromosomes are less significant statically $(\mathrm{P}>0.05$; $\mathrm{P}=0.045$; Students T-test) and there is difference in their relative lengths. In order to better visualize the existing differences in chromosome morphology, ideograms were constructed using the centromere indexes and relative length values (Figure 6).
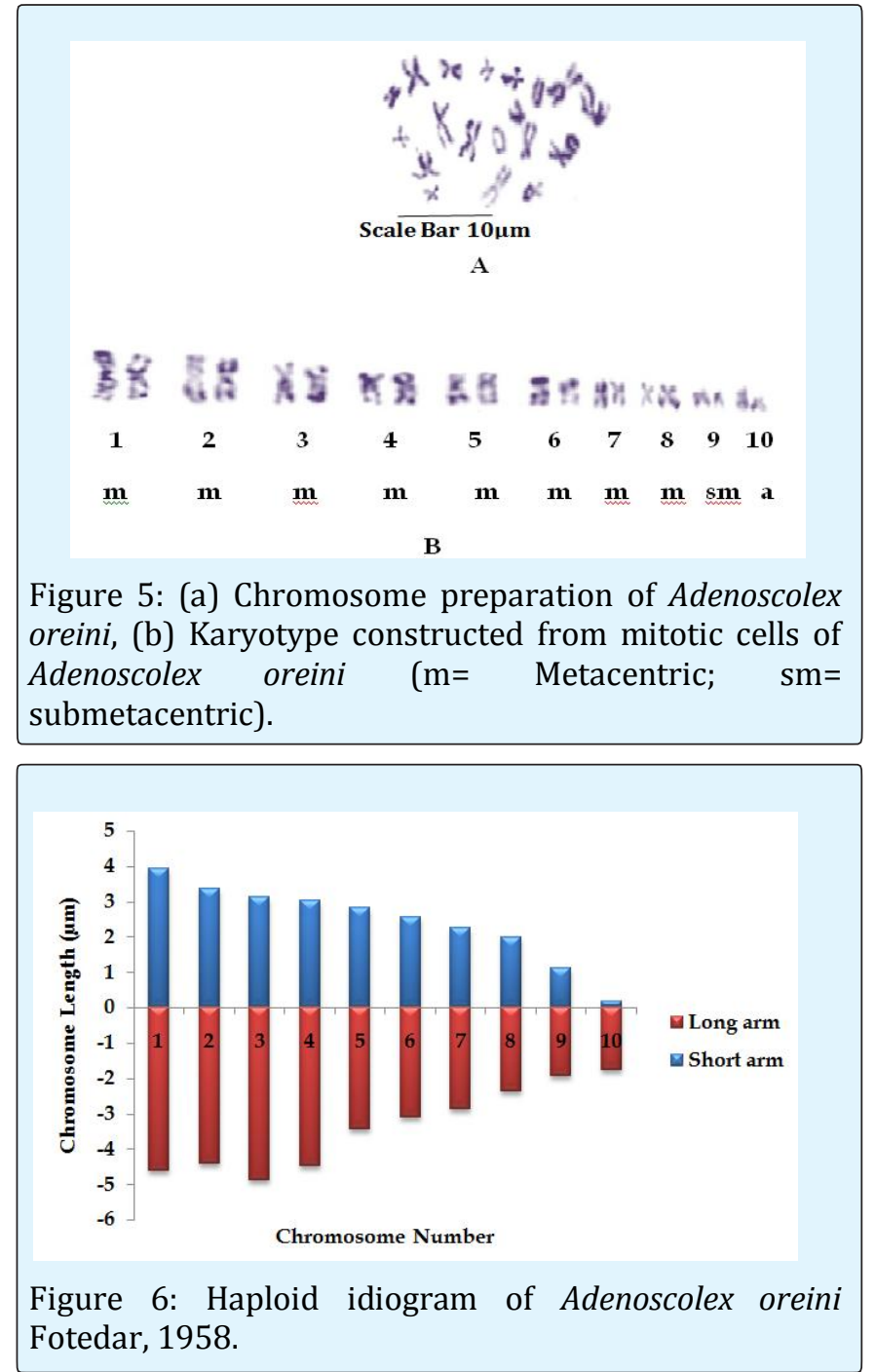

\begin{tabular}{|c|c|c|c|c|c|c|c|c|}
\hline \multirow{3}{*}{$\begin{array}{c}\text { Chromosome } \\
\text { pair number }\end{array}$} & \multirow{2}{*}{$\begin{array}{c}\text { Length of } \\
\text { short arm } \\
(\mu \mathrm{m}) \text { 'S' }\end{array}$} & \multirow{2}{*}{$\begin{array}{l}\text { Length of } \\
\text { long arm } \\
(\mu \mathrm{m}){ }^{\prime} L\end{array}$} & \multirow{2}{*}{\begin{tabular}{|c|} 
Total \\
Length/Absolute \\
Length $(\mu \mathrm{m}) \mathrm{L}+\mathrm{S}$ \\
\end{tabular}} & \multirow{2}{*}{$\begin{array}{l}\text { Arm Ratio } \\
\text { (L/S) }\end{array}$} & \multirow{2}{*}{\begin{tabular}{|c|} 
Relative \\
Length (\%)
\end{tabular}} & \multirow{2}{*}{\begin{tabular}{|c|} 
Centromeric \\
Index (ci) \\
\end{tabular}} & \multirow{2}{*}{\multicolumn{2}{|c|}{ Classification }} \\
\hline & & & & & & & & \\
\hline & 3.93 & 4.63 & 8.56 & 1.18 & 14.69 & 45.91 & Metacentric & \\
\hline 2 & 3.37 & 4.42 & 7.79 & 1.31 & 13.36 & 43.26 & Metacentric & $\mathrm{T}-$ Value $=$ \\
\hline 3 & 3.11 & 4.87 & 7.98 & 1.57 & 13.69 & 38.97 & Metacentric & $\begin{array}{c}80.57 \mathrm{P}- \\
\text { Value = } \\
0.008\end{array}$ \\
\hline 4 & 3.03 & 4.49 & 7.52 & 1.48 & 12.9 & 40.29 & Metacentric & \\
\hline 5 & 2.83 & 3.45 & 6.28 & 1.22 & 10.77 & 45.06 & Metacentric & \\
\hline 6 & 2.57 & 3.11 & 5.68 & 1.21 & 9.74 & 45.25 & Metacentric & T-Value $=$ \\
\hline 7 & 2.27 & 2.88 & 5.15 & 1.27 & 8.84 & 44.08 & Metacentric & $\begin{array}{c}17.65 \mathrm{P}- \\
\text { Value = } \\
0.003\end{array}$ \\
\hline 8 & 1.97 & 2.36 & 4.33 & 1.2 & 7.41 & 45.5 & Metacentric & T-Value $=$ \\
\hline 9 & 1.13 & 1.93 & 3.06 & 1.71 & 5.25 & 36.93 & Submetacentric & c $4.55 \mathrm{P}-$ \\
\hline 10 & 0.17 & 1.77 & 1.94 & 10.41 & 3.33 & 8.76 & Acrocentric & $\begin{array}{c}\text { Value }= \\
0.045\end{array}$ \\
\hline
\end{tabular}

Table 4: Measurements and classification of chromosomes of Adenoscolex oreini Fotedar, 1958. 


\section{Discussion}

Molecular Characterization: The present study used the molecular characterization of Adenoscolex oreini from different water bodies of the Kashmir valley is the first of its kind to determine the complete ITS sequence of $28 \mathrm{~S}$ rDNA in combination with phylogenetic tree to show the interrelationships of this species with other cestode orders. During present observation, the ITS sequence of 28S rDNA showed 954 bp in which 90.78\% sequences are similar to that of Breviscolex orientalis, which belongs to the same family of Capingentidae. Brabec et al and Olson et al showed that Breviscolex orientalis from the fish host of Hemibarbus barbus contains 707 partial sequence and 2075 complete sequence base pairs respectively out of which nearly $90 \%$ sequences matched in our study hence our results confirmed the position of Adenoscolex oreini in the family Capingentidae $[16,29]$. In relation to phylogenetics the present result also showed that, the Adenoscolex oreini is very close to that of family Capingentidae and Caryophyllaidae but with different host species in which the present species were collected from 6 species of fishes. Showed the phylogenetic relationship of the monozoic tapeworms from the morphological characters in which they concluded that the non-monotypic families namely the Capingentidae; Caryophyllaeidae and Lytocestidae, appeared to be paraphyletic, which are in close agreement with the present observations of Adenoscolex oreini studied at molecular level [30].

Only a few caryophyllidean cestodes have been sequenced till date [31-35]. Therefore, it is impossible to assess relationships of individual genera based on current molecular data. In the recent study by Olson et $a l$, relationships of ten species of nine caryophyllidean genera of all families (Balanotaeniidae - 1 species, Capingentidae - 1, Caryophyllaeidae - 3, Lytocestidae 5 species of 4 genera) have been analysed. Their study has shown, as in the case of the present data, incongruency with the current classification, because none of the non-monotypic families formed monophyletic clades. Monobothrioides Fuhrmann \& Baer, 1925 (Lytocestidae) and Balanotaenia Johnston, 1924 (Balanotaeniidae) were most basal groups in a combined analysis of $28 \mathrm{~S}$ and 18S rDNA based on Bayesian inference, whereas other two lytocestid genera viz., Atractolytocestus Anthony, 1958 and Khawia Hsu, 1935 were most derived [35]. Similarly, as in the present study, Adenoscolex, which is the only genus with species found in the intestine of the host, was the most basal Capingentidae in the tree inferred from sequences of the 28S rDNA gene.
Various authors who worked on molecular characterization of family Caryophllidae include Anthony; Jones and Mackiewicz; Chubb, et al.; Buckler, et al.; Scholz, et al.; Oros, et al.; Bouzid, et al.; Oros, et al.; Kralova-Hromadova, et al.; Orosova, et al.; Ash, et al.; Bazsalovicsova, et al.; Scholz, et al.; Bazsalovicsova, et al. who noted different sequences and relationship within the family but none showed the present form [37-48].

It is apparent that the systematics of the Caryophyllidea and its position among the basal tapeworms (Eucestoda) is still unresolved [32,49,50]. Because of the low number of molecular characters used and very low consistency index of the trees, it is premature to speculate on some of the molecular and evolutionary implications of the present data. New material of most genera is needed for analyses of molecular data. These data should help us understand not only the evolutionary relationships of this unique cestode but also the evolution of the life cycles.

\section{Karyology}

The diploid chromosome number of Adenoscolex oreini is 20 and it is the first report of chromosome number of a genus from family Capingentidae of order Caryophyllidea from the Kashmir valley. However, in the family Caryophyllidae the chromosome number has been reported by Mackiewicz and Jones; Grey and Mackiewicz; Vijayaraghavan and Subramanyam; Grey; Grey and Mackiewicz; Petkeviciute and Kuperman; Petkeviciute; Bombarova, et al.; Orosova, et al. for Archigetes appendiculatus $(2 \mathrm{n}=18)$; Hunterella nodulosa $(2 \mathrm{n}=14) ;$ Glaridacis laruei $(2 \mathrm{n}=16)$; Lytocestus indicus $(2 \mathrm{n}=16) ;$ Capingens singularis $(2 \mathrm{n}=14) ;$ Glaridacris catostomi $(2 \mathrm{n}=20)$; Caryophyllaeus laticeps $(2 \mathrm{n}=20)$; Khawia sinensis $(2 \mathrm{n}=16) ;$ Caryophyllaeides fennica $(2 \mathrm{n}=20)$ and Khawia saurogobii $(2 \mathrm{n}=16)$, respectively [2,51-57]. It seems that the chromosome number of Adenoscolex oreini, a member of family Capingentidae is higher as compared to that of the members of family Caryophyllaeidae. The variation in size of smallest bivalent and other bivalents indicates that the somatic chromosome shows a marked variation in the length of longest and shortest chromosome in Adenoscolex oreini. The same has been reported by Mackiewicz and Jones in Hunterella nodulosa. Therefore, this type of chromosome complement may be characteristic of Caryophyllidea in general [50].

In individual species, chromosome morphology differs significantly; a predominance of bi-armed elements (symmetrical karyotypes) was detected in four species of the family Caryophyllaeidae and one lytocestid species, one-armed acrocentric chromosomes 
(asymmetrical karyotypes) prevailed in four species of Caryophyllaeidae and Lytocestidae and the rest of five karyotypes with rather balanced chromosome morphology occurs in both families. Because of this variation, no relevant hypothesis on karyotype evolution can be made on basis of traditional karyological analyses among the four families of the Caryophyllidea. It is noteworthy that recent cladistic analysis by Oros, et al., based on unweighted morphological characters, are only partly congruent with the existing classification into four families that is based on the placement of the internal, longitudinal musculature. It is apparent that classical karyological data are hardly sufficient to resolve phylogenetic and systematic relationships within insufficiently investigated animal groups such as the Caryophyllidea. However, the recent inputs of molecular approaches into the cytogenetics of Caryophyllidea raises hopes that new data will substantially help in elucidating the phylogenetic relationships within this unique group of monozoic tapeworms $[43,44,58-60]$.

\section{Conflict of Interest}

Authors declare that there is no conflict of interest regarding the present research work.

\section{Acknowledgment}

The authors extend their thanks to the authorities of the Department of Zoology \& Biotechnology, University of Kashmir for the facilities provided. TAS is also highly thankful to Prof. Fayaz Ahmad for giving valuable suggestions while compiling this paper.

\section{References}

1. Mackiewicz JS (1982) Caryophyllidea (Cestoidea): Perspectives. Parasitology 84(2): 397-417.

2. Grey AJ (1979) A Comparative Study of the Chromosomes of Twenty Species of Caryophyllidean Tapeworms. In: Dissertation, College of Arts and Sciences, Department of Biology, State University of New York at Albany, USA, pp: 214.

3. Sambrook J, Russell DW (2001) Molecular cloning: a laboratory manual. Cold Spring Harbor Laboratory Press, Cold Spring Harbor, New York.

4. Kralova I, Hanzelova V, Scholz T, Gerdeaux D, Spakulova M (2001) A comparison of the internal transcribed spacer of the ribosomal DNA in Eubothrium crassum and E. salvelini (Cestoda:
Pseudophyllidea), parasites of salmonid fish. Int J Parasitol 31(1): 93-96.

5. Luo HY, Nie P, Zhang YA, Wang GT, Yao WJ (2002) Molecular variation of Bothriocephalus acheilognathi Yamaguti, 1934 (Cestoda: Pseudophyllidea) in different fish host species based on ITS rDNA sequences. Syst Parasitol 52(3): 159-166.

6. Scholz T, Skerikova A, Hanzelova V, Koubkova B, Barus V (2003) Resurrection of Proteocephalus sagittus (Grimm, 1872) (Cestoda: Proteocephalidea) based on morphological and molecular data. Syst Parasitol 56(3): 173-181.

7. Khalil LF, Jones A Bray RA (1994) Keys to the Cestode Parasites of Vertebrates. CAB International, Wallingford, UK.

8. Williams H, Jones A (1994) Parasitic worms of fish. London: Taylor and Francis.

9. Kern CG (1998) Parasitism and the Platyhelminths. Chapman and Hall, London, UK, pp: 544.

10. Rego AA (1999) Scolex morphology of proteocephalid cestodes parasites of Neotropical freshwater fishes. Memorias do Instituto Oswaldo Cruz 94(1): 37-52.

11. Scholz T, de Chambrier A (2003) Taxonomy and biology of proteocephalidean cestodes: current state and perspectives. Helmithologia 40(2): 65-77.

12. Scholz T, Drabek R, Hanzelova V (1998) Scolex morphology of Proteocephalus tapeworms (Cestoda: Proteocephalidae), parasites of freshwater fish in the Palaerctic Region. Folia Parasitol 45(1): 27-43.

13. Levron C, Miquel J, Oros M, Scholz T (2010) Spermatozoa of tapeworms (Platyhelminthes, Eucestoda): advances in ultrastructural and phylogenetic studies. Biol Rev Camb Philos Soc 85(3): 523-543.

14. Boero F (2010) The study of species in the era of biodiversity: a tale of stupidity. Diversity 2(1): 115126.

15. Hoberg EP, Gardner SL, Campbell RA (1999) Systematics of the Eucestoda: advances toward a new phylogenetic paradigm, and observations on the early diversification of tapeworms and vertebrates. Syst Parasitol 42(1): 1-12. 
16. Olson PDD, Littlewood TJ, Bray RA, Mariaux J (2001) Interrelationships and Evolution of the Tapeworms (Platyhelminthes: Cestoda). Mol Phylogenet Evol 19(3): 443-467.

17. Kuchta R, Scholz T, Brabec J, Bray RA (2008) Suppression of the tapeworm order Pseudophyllidea (Platyhelminthes: Eucestoda) and the proposal of two new orders, Bothriocephalidea and Diphyllobothriidea. International Journal for Parasitology 38: 49-55.

18. Yamaguti S (1971) Synopsis of digenetic trematodes of vertebrates. I and II (Volume), Tokyo Japan, Keigaku publishing, pp: 1074.

19. Bauer ON (1987) Key to the parasites of freshwater fishes in the fauna of the U.S.S.R. Academy of Sciences, USSR, Leningrad, Nauka, pp: 583.

20. Chubb JC, Pool DW, Veltkamp CJ (1987) A Key to the species of cestodes (tapeworms) parasitic in British and Irish freshwater fishes. J Fish Biol 31: 517-543.

21. Hoffman GL (1999) Parasites of North American freshwater fishes. $2^{\text {nd }}(\mathrm{edn})$. Ithaca, New York: Cornell University Press, pp: 539.

22. Cunningham CO (1997) Species Variation within the Internal Transcribed Spacer (ITS) Region of Gyrodactylus (Monogenea: Gyrodactylidae) Ribosomal RNA Genes. The Journal of Parasitology 83(2): 215-219.

23. Kralova-Hromadova I, Scholz T, Shinn AP, Cunningham CO, Wootten R, et al. (2003) A molecular study of Eubothrium rugosum (Batsch, 1786) (Cestoda: Pseudophyllidea) using ITS rDNA sequences, with notes on the distribution and intraspecific sequence variation of Eubothrium crassum (Bloch, 1779). Parasitology Research 89(6): 473-479.

24. White MJD (1973) The chromosomes. 6 $6^{\text {th }}$ (edn), Chapman and Hall, London.

25. Petkeviciute R, Kuperman BI (1991) The karyotype of Eubothrium rugosum (Cestoda: Pseudophyllidea). International Journal of Parasitology 21(1): 125-127.

26. Fayaz A (1993) Trematode and Cestode Parasites of Pisces and Aquatic aves of Kashmir, with Histology and Histopathology of Genus Adenoscolex Fotedar, 1958. Ph. D. Thesis of University of Kashmir, Srinagar.
27. Ashiq HR (2008) Determinants of Rich Helminth Parasite Communities in Native Fish Species in Comparison to Poor Helminth Communities in Exotic Fish Species from Jhelum. Ph. D. Thesis of University of Kashmir, Srinagar.

28. Fayaz A, Akhter S, Chishti MZ (2009) Light and Scanning Electron Microscopy of Adenoscolex from the Schizothorax. Oriental Science 14: 129-132.

29. Oros M, Hanzelova V, Scholz T, Mackiewicz JS (2008) Phylogenetic relationships of the monozoic tapeworms (Eucestoda: Caryophyllidea) inferred from morphological characters. Syst Parasitol $70(1): 1-14$.

30. Mariaux J (1998) A molecular phylogeny of the Eucestoda. Journal of Parasitology 84(1): 114-124.

31. Olson PD, Caira JH (1999) Evolution of the major lineages of tapeworms (Platyhelminthes: Cestoidea) inferred from $18 \mathrm{~S}$ ribosomal DNA and elongation factor-1a. The Journal of Parasitology 85(6): 11341159.

32. Kodedova I, Dolezel D, Brouckova M, Jirku M, Hypsa $\mathrm{V}$, et al. (2000) On the phylogenetic positions of the Caryophyllidea, Pseudophyllidea and Proteocephalidea (Eucestoda) inferred from 18S rRNA. International Journal for Parasitology 30(10): 1109-1113.

33. Olson PD, Tkach VV (2005) Advances and trends in the molecular systematics of the parasitic Platyhelminthes. Adv Parasitol 60: 165-243.

34. Waeschenbach A, Webster BL, Bray RA, Littlewood DTJ (2007) Added resolution among ordinal level relationships of tapeworms (Platyhelminthes: Cestoda) with complete small and large subunit nuclear ribosomal RNA genes. Mol Phylogenet Evol 45(1): 311-325.

35. Olson PD, Poddubnaya LG, Littlewood DTJ, Scholz T (2008) On the position of Archigetes and its bearing on the early evolution of the tapeworms. Journal of Parasitology 94(4): 898-904.

36. Anthony JD (1958) Atractolytocestus huronensis n. gen, n. sp. (Cestoda: Lytocestidae) with notes on its morphology. Trans American Microscope Society 77(4): 383-390.

37. Jones AW, Mackiewicz JS (1969) Naturally occurring triploidy and parthenogenesis Atractolytocestus huronensis Anthony (Cestoidea: Caryophyllidea) from Cyprinus carpio L. in North 
America. The Journal of Parasitology 55(6): 11051118.

38. Chubb JC, Kirk R, Wellby I (1996) Caryophyllaeid tapeworm Atractolytocestus huronensis Anthony, 1958 (Markevitschia sagittata Kulakovkaya et Akhmerov, 1965) in carp Cyprinus carpio L. in British Isles-another translocation? In: Abstract of the Spring Meeting of the British Society of Parasitology, University of Wales, pp: 66.

39. Buckler ES, Ippolito A, Holtsford TP (1997) The evolution of ribosomal DNA: divergent paralogues and phylogenetic implications. Genetics 145(3): 821-832.

40. Scholz T, Brabec J, Kralova-Hromadova I, Oros M, Bazsalovicsova E, et al. (2011) Revision of Khawia spp. (Cestoda: Caryophyllidea), parasites of cyprinid fish, including a key to their identification and molecular phylogeny. Folia Parasitol 58(3): 197-223.

41. Oros M, Hanzelova V, Scholz T, Mackiewicz JS (2004) The cestode Atractolytocestus huronensis (Caryophyllidea) continues to spread in Europe: new data on the helminth parasite of the common carp. Dis Aquat Organ 62(1-2): 115-119.

42. Bouzid W, Lek S, Mac M, Hassine OB, Etienne R, et al. (2008) Genetic diversity of Ligula intestinalis (L.) (Cestoda: Diphyllobothriidea) based on analysis of inter-simple sequence repeat markers. Journal of Zoology Systematic Evolution Research 46(4): 289296.

43. Kralova-Hromadova I, Stefka J, Spakulova M, Bombarova $M$, Orosova $M$, et al. (2010) Intraindividual internal transcribed spacer 1 (ITS1) and ITS2 ribosomal sequence variation linked with multiple rDNA loci: a case of triploid Atractolytocestus huronensis, the monozoic cestode of common carp. Int J Parasitol 40(2): 175-181.

44. Orosova M, Kralova-Hromadova I, Bazsalovicsova E, Spakulova M (2010) Karyotype, chromosomal characteristics of multiple rDNA clusters and intragenomic variability of ribosomal ITS2 in Caryophyllaeides fennica (Cestoda). Parasitology International 59(3): 351-357.

45. Ash A, Scholz T, Oros M, Kar PK (2011) Tapeworms (Cestoda: Caryophyllidea), parasites of Clarias batrachus (Pisces: Siluriformes) from the Indomalayan Region. J Parasitol 97(3): 435-459.
46. Bazsalovicsova E, Kralova-Hromadova I, Stefka J, Scholz T, Hanzelova V, et al. (2011) Population study of Atractolytocestus huronensis (Cestoda: Caryophyllidea), an invasive parasite of common carp introduced to Europe: mitochondrial cox1 haplotypes and intragenomic ribosomal ITS2 variants. Parasitol Res 109: 125-131.

47. Bazsalovicsova E, Kralova-Hromadova I, Stefka J, Scholz T (2012) Molecular characterization of Atractolytocestus sagittatus (Cestoda: Caryophyllidea), monozoic parasite of common carp, and its differentiation from the invasive species Atractolytocestus huronensis. Parasitol Res 110(5): 1621-1629.

48. Mackiewicz JS (1994) Order Caryophyllidea van Beneden in Carus, 1863. In: Khalil A, Jones A, et al. (Eds.), Keys to the Cestode Parasites of Vertebrates. CAB International, Wallingford, UK, pp: 21-43.

49. Mackiewicz, JS (2003) Caryophyllidea (Cestoidea): molecules, morphology and evolution. Acta Parasitology 48: 143-154.

50. Mackiewicz, JS, Jones AW (1969) The chromosomes of Hunterella nodulosa Mackiewicz and McCrae, 1962 (Cestoidea: Caryophyllidea). Proceeding of Helminthology Society Washington 36(1): 126-131.

51. Grey AJ, Mackiewicz JS (1974) Chromosomes of the caryophyllidean tapeworm Glaridacris laruei. Experimental Parasitology 36(2): 159-166.

52. Vijayaraghavan S, Subramanyam S (1977) Chromosome number of the cestode Lytocestus indicus. Current Science 46: 312-313.

53. Grey AJ, Mackiewicz JS (1980) Chromosomes of caryophyllidean cestodes: Diploidy, triploidy, and parthenogenesis in Glaridacris catostomi. International Journal for Parasitology 10(5-6): 397407.

54. Petkeviciute R, Kuperman BI (1992) Karyological Investigations of Caryophyllaeus laticeps (Pallas, 1781) (Cestoda: Caryophyllidea). Folia Parasitologica 39(2): 115-121.

55. Petkeviciute R (1998) A chromosome study of Khavia sinensis. Acta Zoology Lithuanium 8(1): 3539.

56. Bombarova M, Vitkova M, Spakulova M, Koubkova B (2009) Telomere analysis of platyhelminths and acanthocephalans by FISH and Southern hybridization. Genome 52(11): 897-903. 
57. Akhter S, Fayaz A, Chishti MZ (2008) Infection Dynamics of Bothriocephalus acheilognathi in The Copepod Intermediate Host. Oriental Science 15: 55-59.

58. Ara J, Khan AR, Fayaz A (2000) First record of a Pseudophyllidean Cestode Bothriocephalus (Rudolphi; 1808) from fishes of Kashmir. Oriental Science 5: 23-26.

59. Brabec J, Scholz T, Kralova-Hromadova I, Bazsalovicsova E, Olson PD (2012) Substitution saturation and nuclear paralogs of commonly employed phylogenetic markers in the Caryophyllidea, an unusual group of nonsegmented tapeworms (Platyhelminthes). Int J Parasitol 42(3): 259-267.

60. Levan A, Fredga K, Sandberg AA (1964) Nomenclature for centromere position on chromosomes. Hereditas 52(2): 201-220. 